\title{
Sistem Penunjang Keputusan Pemilihan Laptop Menggunakan Metode Simple Additive Weighting (Studi Kasus: Seven Computech)
}

\author{
Deny Novianti ${ }^{1}$ \\ Ilmu Komputer \\ STMIK Nusa Mandiri Jakarta \\ http://www.nusamandiri.ac.id/ \\ denynov.dov@bsi.ac.id
}

\author{
Andika Bayu Hasta Yanto ${ }^{2}$ \\ Teknik Industri \\ Universitas Bina Sarana Informatika \\ http://www.bsi.ac.id \\ andika.akx@bsi.ac.id
}

\begin{abstract}
Abstrak - Saat ini laptop bukanlah lagi dianggap sebagai barang yang mewah, tetapi sudah seperti menjadi sebuah kebutuhan. Karena hampir disetiap aktifitas perkantoran, perkuliahan, bahkan di sekolah pun kini sudah menggunakan laptop sebagai alat untuk mengerjakan pekerjaan ataupun tugas. Sebagai pengguna pastinya akan sangat bingung dan kesulitan dalam memilih laptop mana yang harus dibeli sesuai dengan kebutuhan untuk jurusan multimedia. Untuk itu dapat digunakan sebuah metode pengambilan keputusan yang dapat membantu dalam pengambilan keputusan tersebut. Dan metode yang dipilih untuk menyelesaikan permasalahan dengan pilihan beberapa kriteria adalah Simple Additive Weighting (SAW), salah satu metode yang dapat digunakan untuk memecahkan masalah Fuzzy MADM. Dari hasil pengolahan data yang telah dilakukan yang melibatkan beberapa alternatif, dapat dihasilkan manakah laptop terbaik yang sesuai dengan kebutuhan berdasarkan peringkat yang dihasilkan menunjukkan bahwa alternatif yang paling unggul. Dengan demikian Metode Simple Additive Weighting (SAW) merupakan salah satu metode yang dapat digunakan untuk membantu dalam menentukan sebuah keputusan dengan melibatkan beberapa pilihan alternatif yang juga sesuai dengan kriteria yang diinginkan oleh pembuat. Dan pemberian nilai preferensi (bobot) pada data tiap kriteria sangat berpengaruh pada tingkat perangkingan untuk setiap alternatif.
\end{abstract}

\section{Kata Kunci: Laptop, SAW, Fuzzy MADM}

\section{PENDAHULUAN}

Perkembangan zaman yang semakin maju seperti sekarang ini membuat kebutuhan masyarakat juga semakin meningkat. Terlebih lagi didorong dengan adanya kemajuan ilmu pengetahuan dan teknologi yang sangat cepat. Setiap orang dihadapkan pada suatu keadaan dimana dia harus memutuskan untuk memilih satu dari beberapa pilihan yang ada. Suatu masalah dalam kehidupan dapat diselesaikan dengan berbagai cara yang mungkin saja memberikan pemecahan masalah secara langsung atau memberi beberapa alternatif solusi untuk pemecahan masalah (Nasution, 2014).

Oleh karena itu penelitian ini akan membahas sistem pendukung keputusan yang diharapkan dapat membantu karyawan di toko Seven Computech dalam memilih laptop apa yang sesuai dengan kebutuhan pelanggannya khususnya untuk jurusan multimedia. Prosesnya bisa ditentukan berdasarkan kriteria merek, harga, dan spesifikasi (jenis processor, ram, ukuran layar, vga). Hasil yang diberikan oleh sistem sebagai pendukung keputusan dapat memberikan suatu alternatif pemecahan masalah yang ada, sehingga keputusan yang dibuat menjadi lebih baik.

Metode yang dipakai dalam pengambilan keputusan pemilihan laptop ini adalah Simple Additive Weighting (SAW). Metode ini dipilih karena mampu memilih alternatif terbaik dari sejumlah alternatif. Dalam hal ini alternatif yang dimaksud adalah pemilihan laptop terbaik berdasarkan kriteria-kriteria yang ditentukan. Semakin banyak sample data yang digunakan maka semakin tinggi pula tingkat validitas perhitungan yang dihasilkan. Pemberian skala konversi dan bobot preferensi dari setiap bobot kriteria mempengaruhi penilaian dan hasil perhitungan SAW (Supriyanti, 2014)

Alasan lain penulis menggunakan metode Simple Additive Weighting (SAW) karena metode ini menentukan nilai bobot untuk setiap atribut, kemudian dilanjutkan dengan proses perangkingan yang akan menyeleksi alternatif terbaik dari sejumlah alternatif (Hartini, Endang \& Ali, 2013). Tingkat keakuratan data dapat diperoleh secara tepat, karena setiap data yang ada dibandingkan, sehingga seluruh data yang ada dapat berubah secara menyeluruh ketika sebuah data baru dimasukkan ke dalam sistem (Wedhasmara dan 
Wibowo, 2010) Maka dari itu penulis mengambil "Sistem Penunjang Keputusan Pemilihan Laptop Menggunakan Metode Simple Additive Weighting (SAW) Studi Kasus : Seven Computech".

\section{METODE PENELITIAN}

Menurut Sugiyono (2016:9), "Metode Penelitian Kualitatif adalah metode penelitian yang berlandaskan pada filsafat, postpositivisme, digunakan untuk meneliti pada kondisi obyek yang alamiah, (sebagai lawannya adalah eksperimen) dimana peneliti adalah sebagai instrumen kunci. Teknik pengumpulan data dilakukan secara triangulasi (gabungan), analisis data bersifat induktif/kualitatif, dan hasil penelitian kualitatif lebih menekankan makna dari pada generalisasi.

Menurut Alter dalam Kusrini (2007:15) mengemukakan bahwa "DSS merupakan sistem informasi interaktif yang menyediakan informasi, pemodelan, dan pemanipulasian data". Sistem itu digunakan untuk membantu pengambilan keputusan dalam situasi yang semi terstruktur dan situasi yang tidak terstruktur, dimana tak seorang pun tahu secara pasti bagaimana keputusan seharusnya dibuat.

Menurut Nofriansyah (2014:10) mengemukakan bahwa "Metode Simple Additive Weighting sering dikenal dengan istilah metode penjumlahan terbobot". Konsep dasar metode Simple Additive Weighting ini adalah mencari penjumlahan terbobot dari rating kinerja pada setiap alternatif semua atribut. Metode Simple Additive Weighting disarankan untuk penyeleksian dalam sistem pengambilan keputusan multi proses. Metode Simple Additive Weighting merupakan metode yang banyak digunakan dalam pengambilan keputusan yang memiliki banyak atribut. Metode Simple Additive Weighting membutuhkan proses normalisasi matriks keputusan (X) ke suatu skala yang dapat diperbandingkan dengan semua rating alternatif yang ada. Nofriansyah (2014:13) mengemukakan bahwa langkah penyeleksian metode Simple Additive Weighting sebagai berikut:

1. Menentukan kriteria-kriteria yang akan dijadikan acuan dalam pengambilan keputusan, yaitu $\mathrm{Ci}$.

2. Menentukan rating kecocokan setiap alternatifpada setiap kriteria.

3. Membuat matriks keputusan berdasarkan kriteria (Ci), kemudian melakukan normalisasi matriks berdasarkan persamaan yang disesuaikan dengan jenis atribut (atribut keuntungan ataupun atribut biaya) sehingga diperoleh matriks ternormalisasi R.
4. Hasil akhir diperoleh dari proses perangkingan yaitu penjumlahan dari perkalian matriks ternormalisasi $\mathrm{R}$ dengan vektor bobot sehingga diperoleh nilai terbesar yang dipilih sebagai alternatif terbaik (Ai) sebagai solusi.

Formula untuk melakukan normalisasi tersebut adalah:

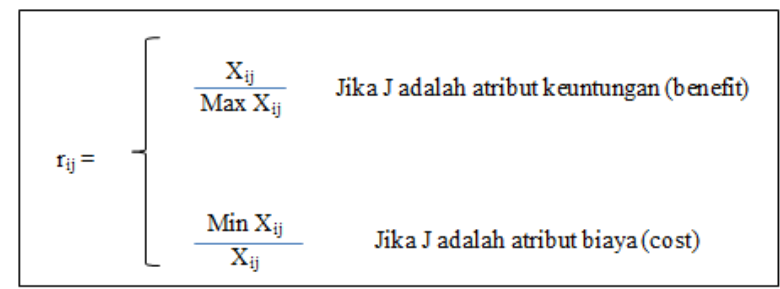

Sumber : Nofriansyah (2014:11)

\section{Gambar 1. Formula Normalisasi}

Keterangan:

a. $\mathrm{r}_{\mathrm{ij}} \quad=$ Rating kinerja ternormalisasi

b. $\mathrm{X}_{\mathrm{ij}} \quad$ = Nilai calon karyawan

c. $\operatorname{Max} X_{i j}=$ Nilai terbesar dari setiap kriteria

d. Min $\mathrm{X}_{\mathrm{ij}}=$ Nilai terkecil dari setiap kriteria

e. Atribut Keuntungan = Jika nilai terbesar dalam atribut tersebut merupakan nilai terbaik

f. Atribut Biaya

$$
\begin{aligned}
&= \text { Jika nilai terkecil dalam } \\
& \text { atribut tersebut } \\
& \text { merupakan } \\
& \text { nilai terbaik }
\end{aligned}
$$

Dimana $\mathrm{r}_{\mathrm{ij}}$ adalah rating kinerja ternormalisasi dari alternatif $A_{i}$ pada atribut $C_{j}, i=1,2, \ldots, m$ dan $j=1$, $2, \ldots, n$. Nilai preferensi untuk setiap alternatif $\left(\mathrm{V}_{\mathrm{i}}\right)$ diberikan sebagai berikut:

$$
V_{i}=\sum_{j=1} W_{j} r_{i j}
$$

Sumber : Nofriansyah (2014:12)

\section{Gambar 2. Rumusan Nilai Preferensi}

Keterangan :

a. $\quad \mathrm{V}_{\mathrm{i}}=$ Rangking untuk setiap alternatif 
b. $\mathrm{W}_{\mathrm{j}}=$ Nilai bobot rangking (dari setiap kriteria)

c. $\mathrm{r}_{\mathrm{ij}}=$ Nilai rating kinerja ternormalisasi

Nilai $V_{i}$ yang lebih besar mengidentifikasikan bahwa alternatif $\mathrm{A}_{\mathrm{i}}$, lebih terpilih.

Keunggulan dari metode Simple Additive Weighting dibandingkan dari metode sistem keputusan yang lain terletak pada kemampuannya dalam melakukan penilaian secara lebih tepat karena didasarkan pada nilai kriteria dan bobot tingkat kepentingan yang dibutuhkan.

Dalam metode Simple Additive Weighting dapat juga menyeleksi alternatif terbaik dari sejumlah alternatif yang ada kemudian dilakukannya proses perangkingan yang jumlah bobot dari semua kriteria dijumlahkan setelah menentukan nilai bobot dari setiap kriteria.

\section{Fuzzy Multiple Attribute Decision Making (FMADM)}

Menurut Kusumadewi dkk (2006:72) menyimpulkan bahwa: Fuzzy Multiple Attribute Decision Making (FMADM) adalah suatu metode yang digunakan untuk mencari alternatif optimal dari sejumlah alternatif dengan kriteria tertentu. Inti dari FMADM adalah menentukan nilai bobot untuk setiap atribut, kemudian dilanjutkan dengan proses perangkingan yang akan menyeleksi alternatif yang sudah diberikan.

\section{HASIL DAN PEMBAHASAN}

\subsection{Menentukan Kriteria-Kriteria}

Menentukan kriteria yang akan dijadikan acuan dalam pengambilan keputusan. Dalam metode penelitian ini ada bobot dan kriteria yang dibutuhkan untuk menentukan laptop terbaik yang paling sering dicari dan sesuai dengan kebutuhan. Berdasarkan wawancara dengan narasumber yaitu Firdaus Amariskan Cahya diperoleh lima kriteria sebagai berikut:

1. C1 : Harga

2. C2 : Jenis Processor

3. C3 : RAM

4. C4 : Ukuran Layar

5. C5 : VGA
Dari masing-masing bobot tersebut, maka dibuat suatu variabel-variabelnya. Dimana dari suatu variabel tersebut akan dirubah ke dalam bilangan fuzzy. Di bawah ini adalah bilangan fuzzy dari bobot setiap alternatif pada setiap kriteria, dinilai dengan 1 sampai 5 , yaitu :

$1=$ Sangat buruk,

2 = Buruk,

$3=$ Cukup,

$4=$ Baik

$5=$ Sangat Baik.

Sedangkan tingkat kepentingan setiap kriteria, juga dinilai dengan 1 sampai 5, yaitu:

$1=$ Sangat Rendah,

$2=$ Rendah,

$3=$ Cukup,

$4=$ Tinggi,

$5=$ Sangat Tinggi

Dari masing-masing bobot tersebut, maka dibuat suatu variabel yang akan dikonversikan ke dalam bilangan fuzzy.

Alternatif yang diperlukan dalam pengambilan keputusan pemilihan laptop terbaik untuk jurusan multimedia dapat dilihat pada tabel berikut:

Tabel 1.

Data Kriteria

\begin{tabular}{|c|c|c|c|}
\hline Bobot & Kode & Kriteria & Keterangan \\
\hline 0,30 & C1 & Harga & Biaya \\
\hline 0,25 & C2 & $\begin{array}{c}\text { Jenis } \\
\text { Processor }\end{array}$ & Keuntungan \\
\hline 0,20 & C3 & RAM & Keuntungan \\
\hline 0,10 & C4 & $\begin{array}{c}\text { Ukuran } \\
\text { Layar }\end{array}$ & Keuntungan \\
\hline 0,15 & C5 & VGA & Keuntungan \\
\hline
\end{tabular}

Tabel 2.

Nilai Kepentingan Kriteria

\begin{tabular}{|c|c|c|}
\hline Kriteria & Sub Kriteria & Nilai \\
\hline \multirow{7}{*}{ Harga } & Rp 3.100.000 & \\
\cline { 2 - 3 } & Rp 4.000.000 & 5 \\
& Rp 3.400.000 & \\
& - & \\
& Rp 4.000.000 & \\
& & \\
\hline
\end{tabular}




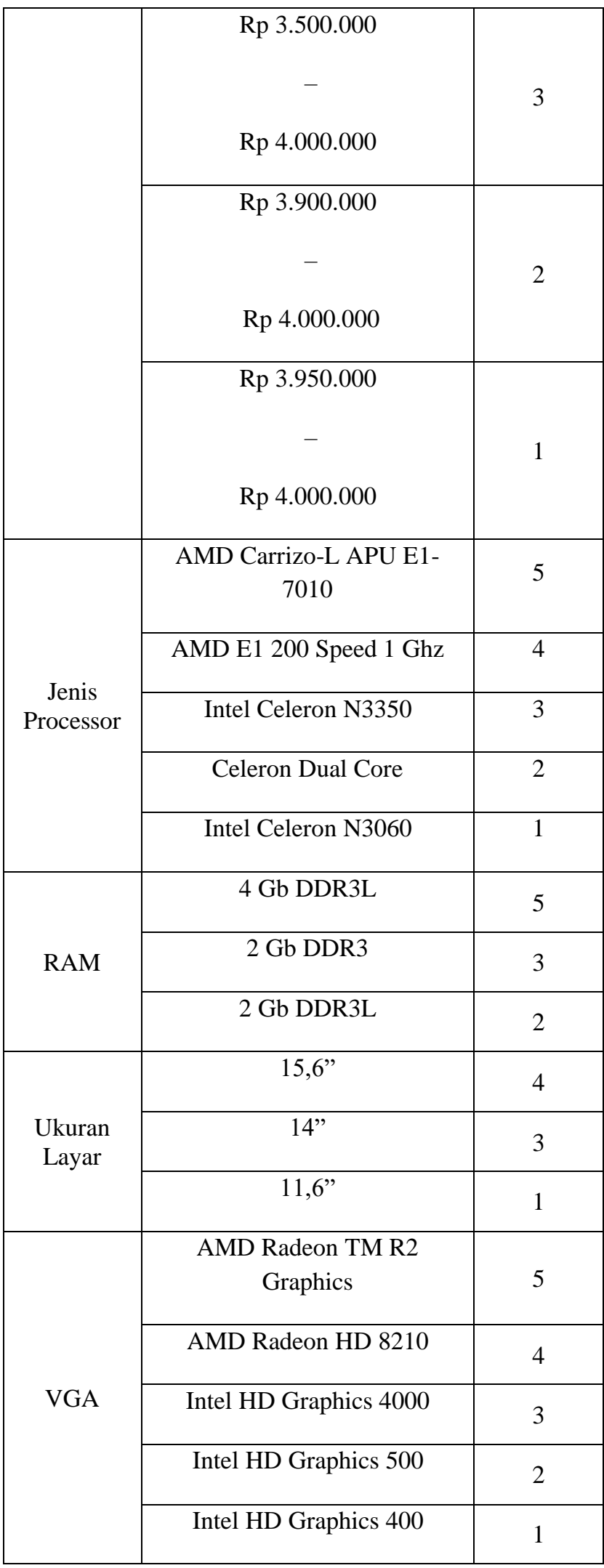

Karena setiap nilai yang diberikan pada setiap alternatif di setiap kriteria merupakan nilai kecocokan (nilai terbesar adalah nilai terbaik), maka empat kriteria saja yang di asumsikan sebagai kriteria keuntungan, dan satu sebagai kriteria biaya.
Pengambil keputusan memberikan bobot preferensi sebagai berikut :

$\mathrm{W}=(0,30 ; 0,25 ; 0,20 ; 0,10 ; 0,15)$

\subsection{Menentukan Rating Kecocokan}

Tabel 3.

Rating Kecocokan Dari Setiap Alternatif Pada Setiap Kriteria

\begin{tabular}{|c|c|c|c|c|c|}
\hline \multirow{2}{*}{ Alternatif } & \multicolumn{5}{|c|}{ Kriteria } \\
\cline { 2 - 6 } & C1 & C2 & C3 & C4 & C5 \\
\hline A1 & 2 & 3 & 5 & 3 & 2 \\
\hline A2 & 3 & 5 & 2 & 4 & 5 \\
\hline A3 & 5 & 4 & 3 & 4 & 4 \\
\hline A4 & 1 & 1 & 5 & 1 & 1 \\
\hline A5 & 4 & 2 & 3 & 1 & 3 \\
\hline
\end{tabular}

\subsection{Membuat Matrik Keputusan $X$}

Pertama-tama, dilakukan normalisasi matriks X berdasarkan persamaan (1). Dari Tabel IV.3 diubah ke dalam matriks keputusan $\mathrm{X}$ dengan data sebagai berikut:

$X=\left(\begin{array}{ccccc}2 & 3 & 5 & 3 & 2 \\ 3 & 5 & 2 & 4 & 5 \\ 5 & 4 & 3 & 4 & 4 \\ 1 & 1 & 5 & 1 & 1 \\ 4 & 2 & 3 & 1 & 3\end{array}\right)$

\subsection{Melakukan Normalisasi Matrik Keputusan $X$}

Cara Menghitung Nilai Rating Kinerja Ternomalisasi $\left(R_{\mathrm{ij}}\right)$ Dari Alternatif $\mathrm{A}_{\mathrm{i}}$ Pada Kriteria $\mathrm{Cj}$ :

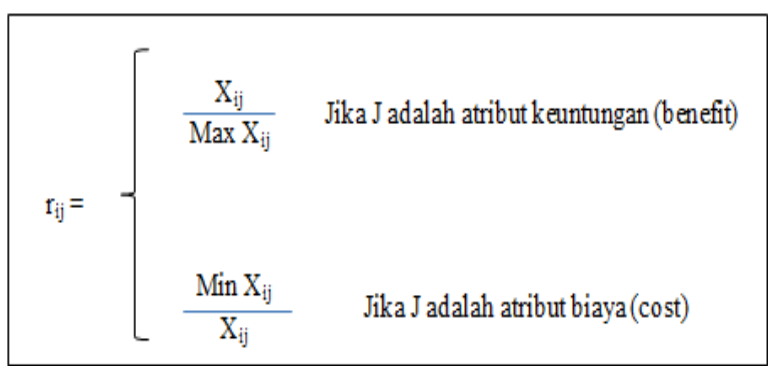

1. Normalisasi Untuk Harga

$$
\begin{aligned}
& r_{11}=0,50 \\
& r_{21}=0,33 \\
& r_{31}=0,20 \\
& r_{41}=1,00 \\
& r_{51}=0,25
\end{aligned}
$$


2. Normalisasi Untuk Jenis Processor

$r_{12}=0,60$

$\mathrm{r}_{22}=1,00$

$\mathrm{r}_{32}=0,80$

$\mathrm{r}_{42}=0,20$

$r_{52}=0,40$

3. Normalisasi Untuk RAM

$\mathrm{r}_{13}=1,00$

$r_{23}=0,40$

$\mathrm{r}_{33}=0,60$

$\mathrm{r}_{43}=1,00$

$\mathrm{r}_{53}=0,60$

4. Normalisasi Untuk Ukuran Layar

$r_{14}=0,75$

$\mathrm{r}_{24}=1,00$

$\mathrm{r}_{34}=1,00$

$\mathrm{r}_{44}=0,25$

$\mathrm{r}_{54}=0,25$

5. Normalisasi Untuk VGA

$\mathrm{r}_{15}=0,40$

$\mathrm{r}_{25}=1,00$

$\mathrm{r}_{35}=0,80$

$\mathrm{r}_{45}=0,20$

$r_{55}=0,60$

Hasil Dari Nilai Rating Kinerja Ternormalisasi $\left(\mathbf{R}_{\mathbf{i j}}\right)$

Membentuk sebuah matriks R:

$R=\left(\begin{array}{ccccc}0,50 & 0,60 & 1,00 & 0,75 & 0,40 \\ 0,33 & 1,00 & 0,40 & 1,00 & 1,00 \\ 6,20 & 0,80 & 0,60 & 1,00 & 0,80 \\ 1,00 & 0,20 & 1,00 & 0,25 & 0,20 \\ 0,25 & 0,40 & 0,60 & 0,25 & 0,60\end{array}\right)$

\subsection{Melakukan Proses Perangkingan}

Hasil yang diperoleh dari perkalian dan penjumlahan tersebut akan mendapatkan alternatif terbaik dengan menggunakan persamaan (2). Berikut adalah hasil dari perangkingannya:

$$
V_{i}=\sum_{j=1} W_{j} r_{i j}
$$

Keterangan :

$\mathrm{V}_{\mathrm{i}} \quad$ = Rangking untuk setiap alternatif

$\mathrm{W}_{\mathrm{j}}=$ Nilai bobot rangking (dari setiap kriteria)

$\mathrm{r}_{\mathrm{ij}} \quad=$ Nilai rating kinerja ternormalisasi

Maka hasil perhitungannya adalah:

$$
\begin{aligned}
& \mathrm{V}_{1}=0,64 \\
& \mathrm{~V}_{2}=0,68 \\
& \mathrm{~V}_{3}=0,60 \\
& \mathrm{~V}_{4}=0,61 \\
& \mathrm{~V}_{5}=0,41
\end{aligned}
$$

Hasil dari perhitungan di atas dapat disimpulkan hasil dengan perangkingan nilai $\mathrm{V}_{\mathrm{i}}$ dari nilai terbesar terkecil, sehingga di dapat alternatif terbaik rekomendasi pemilihan laptop berdasarkan nilai tertinggi terdapat pada tabel berikut ini:

Tabel 4.

Hasil Perangkingan

\begin{tabular}{|c|c|c|c|c|c|}
\hline No. & Alternatif & \multicolumn{3}{|c|}{ Hasil Akhir } & Rangking \\
\hline 1 & Asus X441NA & 0,64 & 0,22 & $22 \%$ & 2 \\
\hline 2 & Asus X450YA & 0,68 & 0,23 & $23 \%$ & 1 \\
\hline 3 & $\begin{array}{c}\text { Acer Aspire V5- } \\
123\end{array}$ & 0,60 & 0,20 & $20 \%$ & 4 \\
\hline 4 & $\begin{array}{c}\text { HP BS003TU } \\
5\end{array}$ & 0,61 & 0,21 & $21 \%$ & 3 \\
\hline & Lenovo IP210 & 0,41 & 0,14 & $14 \%$ & 5 \\
\hline
\end{tabular}




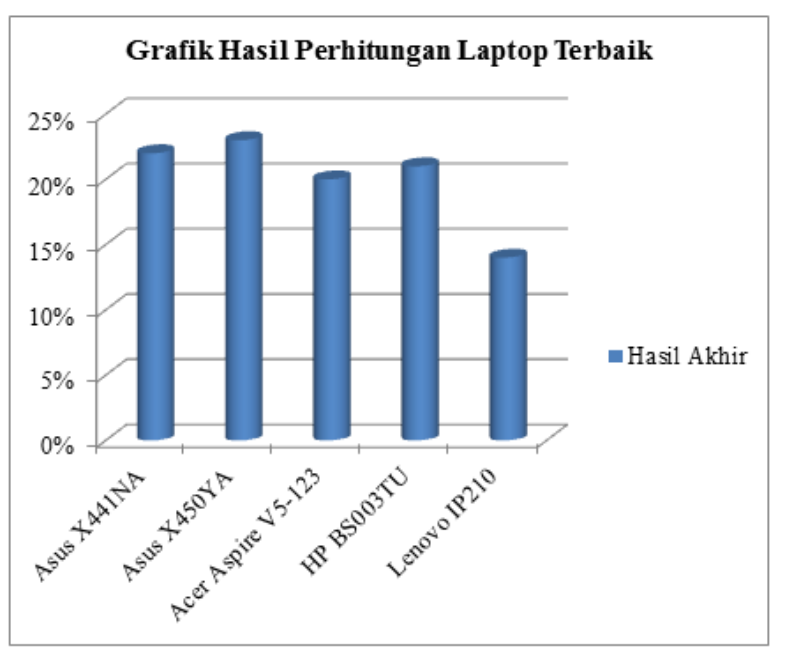

Gambar 3. Grafik Hasil Perhitungan Laptop Terbaik

Nilai terbesar ada pada $V_{2}$ sehingga alternatif $A_{2}$ adalah alternatif yang terpilih sebagai alternatif yang terbaik. Dengan kata lain Asus X450YA terpilih sebagai laptop terbaik untuk jurusan multimedia di smk.

\section{KESIMPULAN}

Setelah melalui beberapa tahapan perhitungan, penulis dapat memberikan kesimpulan mengenai pemilihan laptop terbaik untuk jurusan multimedia dengan mengambil lima besar alternatif yang terdapat pada toko Seven Computech Bekasi. Hasil penelitian cukup membantu untuk menentukan laptop terbaik yang digunakan oleh jurusan multimedia. Dapat dilihat dari hasil perhitungan yang menunjukkan bahwa Alternatif yang paling unggul adalah Asus X450YA dengan hasil akhir $23 \%$, Asus X441NA $=22 \%$, HP BS003TU $=21 \%$, Acer Aspire V5-123 $=20 \%$, dan di posisi terakhir ada Lenovo IP210 $=14 \%$. Metode Simple Additive Weighting (SAW) merupakan salah satu metode yang dapat digunakan untuk membantu dalam menentukan sebuah keputusan dengan melibatkan beberapa pilihan alternatif yang juga sesuai dengan kriteria yang diinginkan oleh pembuat. Dan pemberian nilai preferensi (bobot) pada data tiap kriteria sangat berpengaruh pada tingkat perangkingan untuk setiap alternatif.

\section{REFERENSI}

Hartini, D., Ruskan, E., \& Ibrahim, A. (2013). Jurnal Sistem Informasi (JSI). Jurnal Sistem , 546565.

Kusrini. (2007). Konsep dan Aplikasi Sistem Pendukung Keputusan. Yogyakarta: CV ANDI OFFSET .

Nasution, I. (2014). Sistem Pendukung Keputusan Penentuan Pemilihan Laptop Dengan Menerapkan Fuzzy Tahani. Pelita Informarika Budi Darma .

Nofriansyah, D. (2014). Konsep Data Mining Vs Sistem Pendukung Keputusan. Yogyakarta: DEEPUBLISH.

Sugiyono. (2016). Metode Penelitian Kuantitatif, Kualitatif, dan R\&D. Bandung: CV ALFABET.

Supriyanti, W. (2014). Rancang Bangun Aplikasi Sistem Pendukung Keputusan Penerima Beasiswa dengan Metode SAW. Citec Journal, l(1).

Wahana. (2011). Jago Merakit Komputer Tanpa Kursus. Yogyakarta: CV ANDI OFFSET.

Wahana. (2014). Pengenalan, Permasalahan, dan Penanganan Hardware Komputer. Yogyakarta: CV ANDI OFFSET.

Wedhasmara, A. (2010). Sistem Pendukung Keputusan Pemilihan Pembelian Kendaraan Bermotor Dengan Metode SAW. Jurnal Sistem Informasi (JSI). 